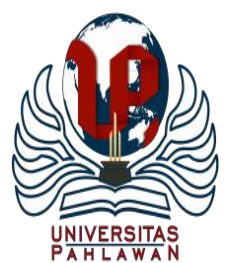

Edukatif : Jurnal Ilmu Pendidikan Volume 3 Nomor 6 Tahun 2021 Halm 3544 - 3552 EDUKATIF: JURNAL ILMU PENDIDIKAN

Research \& Learning in Education

https://edukatif.org/index.php/edukatif/index

\title{
Pengaruh Status Sosial Ekonomi, Pendidikan Pengelolaan Keuangan Keluarga dan Literasi Keuangan terhadap Manajemen Keuangan Pribadi Siswa Akuntansi SMK
}

\author{
Mega Zullyana Dewi ${ }^{1 凶}$, Agung Listiadi ${ }^{2}$ \\ Program Studi Pendidikan Akuntansi, Universitas Negeri Surabaya, Indonesia ${ }^{1,2}$ \\ E-mail : mega.17080304075@ mhs.unesa.ac.id ${ }^{1}$, agunglistiadi@ unesa.ac.id ${ }^{2}$
}

\begin{abstract}
Abstrak
Penelitian ini bertujuan menganalisis pengaruh status sosial ekonomi, pendidikan pengelolaan keuangan keluarga, dan literasi keuangan terhadap manajemen keuangan pribadi siswa akuntansi SMK Ipiems Surabaya. Penelitian ini termasuk penelitian asosiatif kausal dengan sampel 80 siswa akuntansi. Teknik sampel yang digunakan adalah teknik sampling jenuh dengan teknik pengumpulan data berupa angket atau kuisioner dan tes. Teknik analisis data penelitian ini adalah analisis non parametric Kendall's Tau- $b$ dengan aplikasi program IBM SPSS versi 25 . Hasil penelitian ini diperoleh nilai signifikansi atau sig. (2-tailed) yaitu sebesar 0,148 dan nilai koefisien korelasi -0,116. Hal ini membuat kesimpulan bahwa pengaruh antara status sosial ekonomi terhadap manajemen keuangan pribadi siswa akuntansi SMK Ipiems Surabaya adalah tidak signifikan, sangat lemah, dan tidak searah. Hasil analisis juga diperoleh nilai signifikansi atau sig. (2-tailed) yaitu sebesar 0,000 dan nilai koefisien korelasi $+0,479$. Hal ini dapat disimpulkan bahwa pengaruh antara pendidikan pengelolaan keuangan terhadap manajemen keuangan pribadi siswa akuntansi SMK Ipiems Surabaya adalah signifikan, cukup, dan searah. Hasil penelitian ini juga diperoleh nilai signifikansi atau sig. (2-tailed) yaitu sebesar 0,445 dan nilai koefisien korelasi $+0,062$. Hal ini membuat kesimpulan bahwa pengaruh antara literasi keuangan terhadap manajemen keuangan pribadi siswa akuntansi SMK Ipiems Surabaya adalah tidak signifikan, sangat lemah, dan searah.

Kata Kunci: Status Sosial Ekonomi,Pendidikan Pengelolaan Keuangan Keluarga, Literasi Keuangan dan Manajemen Keuangan Pribadi.
\end{abstract}

\begin{abstract}
This study aims to analyze the effect of socioeconomic status, family financial management education, and financial literacy on the personal financial management of accounting students at SMK Ipiems Surabaya. This research is a causal associative type with a sample of 80 students. Saturated sampling technique and data collection techniques in the form of questionnaires or questionnaires and tests. The data analysis technique is non-parametric analysis of Kendall's Tau-b application of IBM SPSS version 25. The result is a significance value or sig. (2-tailed) is 0.148 and the correlation coefficient is -0.116. So it can be concluded that the effect of socioeconomic status on students' personal financial management is insignificant, very weak, and not unidirectional. The result is a significance value or sig. (2-tailed) is 0.000 and the correlation coefficient is $+0.479 * *$ So it can be concluded that the effect of financial management education on students' personal financial management is significant, sufficient, and unidirectional. The result is a significance value or sig. (2-tailed) is 0.445 and the correlation coefficient is +0.062 . So it can be concluded that the effect of financial literacy on students' personal financial management is insignificant, very weak, and unidirectional. Keywords: Socio-Economic Status, Family Financial Management Education, Financial Literacy and Personal Financial Management
\end{abstract}

Copyright (c) 2021 Mega Zullyana Dewi, Agung Listiadi

$\triangle$ Corresponding author

Email : mega.17080304075@mhs.unesa.ac.id

DOI $\quad:$ https://doi.org/10.31004/edukatif.v3i6.965

ISSN 2656-8063 (Media Cetak)

ISSN 2656-8071 (Media Online)

Edukatif : Jurnal Ilmu Pendidikan Vol 3 No 6 Tahun 2021 p-ISSN 2656-8063 e-ISSN 2656-8071 

terhadap Manajemen Keuangan Pribadi Siswa Akuntansi SMK - Mega Zullyana Dewi, Agung Listiadi DOI: https://doi.org/10.31004/edukatif.v3i6.965

\section{PENDAHULUAN}

Indonesia termasuk salah satu dari beberapa negara berkembang yang termasuk dalam jumlah penduduk terbanyak keempat dalam kategori jumlah penduduk dunia. Indonesia yang banyak jumlah penduduknya, harus mampu menghadapi Masyarakat Ekonomi Asean atau disebut MEA. Kemampuan untuk menghadapi MEA yang merupakan pendorong perekonomian masyarakat Asean dapat berupa sikap selektif ketika memilih produk atau jasa agar tidak mudah terpengaruh oleh penawaran pasar, semangat dalam persaingan mendapatkan pekerjaan karena lapangan pekerjaan terbuka bebas untuk negara lain, dan pandai dalam manajemen keuangan.

Manajemen keuangan pribadi merupakan salah satu kecerdasan finansial yang dimiliki oleh manusia salah satunya sebagai siswa. Siswa yang melakukan pengelolaan keuangan yang tepat, akan memperoleh manfaat keuangan yang dimiliki secara maksimal. (Dew \& Xiao, 2011) memberikan pernyataan tentang manajemen keuangan pribadi yang dimana proses perencanaan keuangan dan pengendalian keuangan pribadi meliputi manajemen pemasukan, pengelolaan pengeluaran, tabungan, dan investasi. Manajemen keuangan yang bertahap ini muncul karena perbedaan sumber daya keuangan yang dimiliki antar invidu. Individu akan mendahulukan kepentingan dalam pengelolaan pemasukan dan pengeluaran keuangan. Kemudian, menuju perilaku menabung dan investasi yang merupakan perilaku pengelolaan keuangan yang paling jarang.

Pengelolaan keuangan yang dilakukan siswa berupa pengelolaan dalam mengontrol pengeluaran keuangan pribadi yang dilakukan secara terus menerus. Ketika siswa sulit mengontrol pengeluaran yang dilakukan secara terus menerus dan tak terbatas jumlahnya, maka menunjukkan bahwa siswa tersebut memiliki literasi keuangan yang buruk. Literasi keuangan yang dimiliki siswa akan menjadi pedoman siswa dalam melakukan manajemen keuangan pribadinya. Siswa juga dapat mengolah dan memilah informasi sebelum membuat keputusan keuangan.

(Yuwan Lestari, 2020) memberi pernyataan bahwa literasi keuangan adalah pengetahuan tentang keuangan yang ditempuh dalam mencapai kesejahteraan. Literasi keuangan menjadikan individu lebih siap menghadapi globalisasi keuangan. Literasi juga merupakan suatu hal penting yang wajib dimiliki individu dalam mencapai kesejahteraan pada bidang keuangan artinya setiap individu yang memiliki perencanaan keuangan dengan tepat akan membuat individu tersebut terhindar dari masalah keuangan dan dapat menemukan solusi jika terjadi masalah keuangan. Menurut (Cude, 2006) beberapa negara telah menyadari bahwa pentingnya literasi keuangan di kelas. Negara-negara ini memiliki standar keuangan pribadi yang diberikan pada sistem pendidikan sebagai upaya untuk mengukur literasi keuangan yang difokuskan pada siswa sekolah menengah. Literasi keuangan siswa juga diperlukan dari peran orang tua sebagai agen sosialisasi utama dalam pengelolaan keuangan sejak dini. Oleh karena itu, orang tua seharusnya memiliki literasi keuangan yang dapat diperoleh dari pendidikan maupun informasi-informasi yang tersedia.

(Margaretha \& Arief, 2015) mengemukakan bahwa literasi keuangan membantu setiap orang dalam perencanaan keuangan sehingga nilai waktu uang dapat maksimal dan keuntungan yang didapatkan semakin besar. Keuntungan yang dimaksudkan adalah keuntungan dalam mengelola keuangan dengan baik sehingga kita akan terhindar dari masalah keuangan. (Sundarasen et al., 2016) juga menyatakan bahwa literasi keuangan adalah pengetahuan dan kesadaran dalam perencanaan keuangan serta dampaknya terhadap pengelolaan keuangan adalah tugas utama orang tua. Siswa perlu dididik dan dibimbing pada setiap tahap siklus keuangan mereka agar sesuai dengan tahap kebutuhan hidup mereka. Orang tua berperan penting dalam membentuk karakter anak (Anggraini \& Karneli, 2021). Orang tua yang memberikan literasi keuangan pada anak yang berperan sebagai siswa pada pembelajaran akan mampu mengurangi kesalahan manajemen keuangan pada siswa. Sehingga, siswa dapat secara mandiri dan bertanggung jawab dalam memanajemen keuangan pribadinya dengan literasi keuangan yang diperolehnya dari orang tua, lembaga pendidikan, maupun sumber informasi keuangan lainnya. 
(Jorgensen dalam Rosa \& Listiadi, 2020) menyatakan bahwa siswa yang belajar keuangan dari kedua orang tuanya cenderung memiliki sikap keuangan yang lebih baik. Sikap keuangan yang lebih baik ini berdasarkan pada pelajaran keuangan orang tua seperti menabung yang biasanya dilakukan oleh siswa dan diterapkan sejak dini. (Cude, 2006) juga mengemukakan bahwa terdapat pengaruh anggota keluarga dalam manajemen keuangan siswa. Anggota keluarga yang dimaksudkan adalah saudara kandung dan orang tua yang merupakan anggota keluarga terdekat siswa. Siswa saling bertukar pendapat mengenai manajemen keuangan dengan saudara kandung. Orang tua yang juga termasuk anggota keluarga yang mempengaruhi manajemen keuangan siswa, merupakan pemeran utama dalam sosisalisasi keuangan pada siswa yang terjadi sejak dini. (Syuliswati, 2020) juga mengemukakan bahwa pendidikan pengelolaan keuangan keluarga difokuskan pada perilaku dalam mengatur uang dan pemahaman tentang nilai uang. Sehingga pendidikan pengelolaan keuangan keluarga memiliki peran penting dalam mempengaruhi pola perilaku keuangan individu. Oleh karena itu, jika pendidikan pengelolaan keuangan keluarga yang diberikan positif maka akan berdampak positif pula pada perilaku keuangan individu tersebut.

Manajemen keuangan pribadi siswa juga memiliki hubungan erat terhadap status sosial ekonomi. Status sosial ekonomi merupakan perpaduan antara kondisi sosial yang berkaitan dengan kedudukan sosial dan kondisi ekonomi yang berkaitan dengan penghasilan atau pekerjaan kedua orang tua siswa. Status sosial ekonomi akan memberi pengaruh pendidikan orang tua kepada anaknya. Salah satu pendidikan terhadap anak adalah pendidikan pengelolaan keuangan dengan didasari literasi keuangan yang baik sehingga menyebabkan anak dapat melakukan manajemen keuangan pribadinya dengan baik.

(Rahayu, 2011) menyatakan bahwa status sosial ekonomi didasarkan pada pekerjaan, penghasilan, tanggungan keluarga, dan pendidikan. (Saifi \& Mehmood, 2011) juga menyatakan bahwa status sosial ekonomi merupakan tolak ukur yang berasal dari gabungan kedudukan ekonomi dan kedudukan sosial seseorang atau keluarga kepada orang lain atau masyarakat, serta berasal dari pendidikan, pekerjaan dan pendapatan. Pendapatan biasanya didefinisikan sebagai gaji, upah, keuntungan, dan aliran pendapatan lain yang diterima. Pendidikan dalam lingkup status soaial ekonomi merupakan pencapaian pendidikan berdasarkan nilai atau gelar yang menjadi tolak ukur pencapaian individu dalam upaya perolehan pendapatan. Sehingga, pendidikan berperan dalam pendapatan. Kedudukan pendidikan yang tinggi memiliki hubungan dengan tingkat pendapatan yang baik. Sedangkan kedudukan pendidikan yang rendah memiliki hubungan dengan tingkat pendapatan yang kurang baik. Pekerjaan juga termasuk dalam komponen status ekonomi sosial yang meliputi pendidikan dan pendapatan. Ketiga komponen status sosial ekonomi ini menyebabkan adanya stratifikasi orang dengan status ekonomi sosial yang rendah dan tinggi. (Chotimah et al., 2017) juga mengemukakan bahwa status sosial ekonomi mempunyai peran terhadap perkembangan seorang anak. Keluarga dengan status sosial ekonomi baik akan melakukan pemenuhan kebutuhan dan merencanakan masa depan anaknya. Oleh karena itu, perkembangan seorang anak akan terjamin jika status sosial ekonomi keluarganya baik.

Menurut (Nidar \& Bestari, 2012) terdapat faktor-faktor yang dapat mempengaruhi melek keuangan pribadi adalah faktor internal yang berhubungan dengan pribadi seseorang dan faktor eksternal yang berhubungan dengan lingkungan. Faktor-faktor yang dimaksudkan meliputi kondisi ekonomi, karakteristik sosial dan ekonomi, karakteristik keluarga, pendidikan keuangan, karakteristik demografi, pengalaman keuangan, dan kondisi geografis.

Faktor pertama dalam pengaruh keuangan pribadi pada riset ini yaitu karakteristik sosial dan kondisi ekonomi. (Astuti, 2016) mengemukakan bahwa terdapat tiga faktor yang mempengaruhi status sosial ekonomi yaitu penghasilan, pekerjaan, pendidikan. Teori ini didukung oleh teori Ahmadi (dalam Chotimah, Chusnul; Rohayati, 2015) menyatakan tentang status sosial ekonomi pada orang tua yang memiliki dampak dalam pengalaman dan tindakan pada anaknya. Namun teori ini berbeda dengan riset (Chotimah, Chusnul; Rohayati, 
2015) yang memberi pernyataan tentang status sosial ekonomi pada orang tua tidak memberi dampak positif yang relevan dalam manajemen keuangan pribadi.

Faktor kedua dalam memberi pengaruh tentang keuangan pribadi pada riset ini yaitu pendidikan keuangan di keluarga.(Suhartini, 2007) menyebutkan bahwa pengelolaan keuangan keluarga dilakukan orang tua untuk merencanakan keuangan individu agar tercapai tujuan yang diinginkan. (Mandell, 2008) menyebutkan pada hasil surveinya bahwa pendidikan orang tua mempengaruhi tingkat literasi keuangan siswa. (Shim et al., 2010) mendukung teori ini dengan menyatakan bahwa pembelajaran moneter yang diadaptasi individu adalah melalui sikap keuangan yang dicontohkan orang tua. Namun teori ini berbeda dengan riset yang telah dilakukan oleh (Chotimah, Chusnul; Rohayati, 2015) yaitu individu yang telah mendapatkan pendidikan keuangan dari orang tua sejak dini seharusnya dapat melakukan manajemen keuangannya dengan bijak, namun pada kenyataan masih buruk dalam manajemen keuangan.

Faktor ketiga yang dapat mempengaruhi keuangan pribadi adalah literasi keuangan.(Yushita, 2017) menyatakan bahwa literasi keuangan akan membantu setiap orang untuk meningkatkan nilai waktu uang dan keuntungan yang didapatkan oleh individu. (Laily, 2016) menyebutkan pada hasil penelitiannya bahwa literasi keuangan mempunyai pengaruh secara langsung dalam perilaku keuangan. Namun, teori ini berbanding terbalik dengan penelitian (Maulita \& Mersa, 2017) bahwa ternyata variabel literasi keuangan belum mampu memberikan pengaruh terhadap manajemen keuangan pribadi mahasiswa politeknik negeri samarinda.

Berdasarkan pemaparan tersebut, maka menunjukkan bahwa terdapat gap yaitu antara kenyataan di lapangan dalam kondisi ideal baik secara empiris maupun teoritis, sehingga peneliti berminat untuk mengkaji mengenai manajemen keuangan pribadi yang ditunjukkan siswa smk akuntansi. Penelitian ini memiliki tujuan yaitu dapat mengetahui dampak Status Sosial Ekonomi, Pendidikan Pengelolaan Keuangan Keluarga, dan Literasi Keuangan terhadap Manajemen Keuangan Pribadi Siswa SMK Akuntansi.

\section{METODE PENELITIAN}

Penelitian ini dilakukan dengan pendekatan kuantitatif yang datanya merupakan bentuk angka dan bentuk analisa statistik yang memiliki tujuan yaitu untuk mengetahui pengaruh dalam variabel independen terhadap variabel dependen. Populasi dan sampel pada riset ini yaitu 80 siswa akuntansi SMK Ipiems Surabaya meliputi 36 siswa kelas X AKL, 17 siswa kelas XI AKL, dan 27 siswa kelas XII AKL. Teknik sampel yang digunakan merupakan teknik sampling jenuh. Penelitian ini dilaksanakan di SMK Ipiems Surabaya yang beralamat di Jl. Raya Menur No. 125, Manyar Sabrangan, Kecamatan Mulyorejo, Kota Surabaya. Rancangan Penelitian ditunjukkan pada gambar 1.

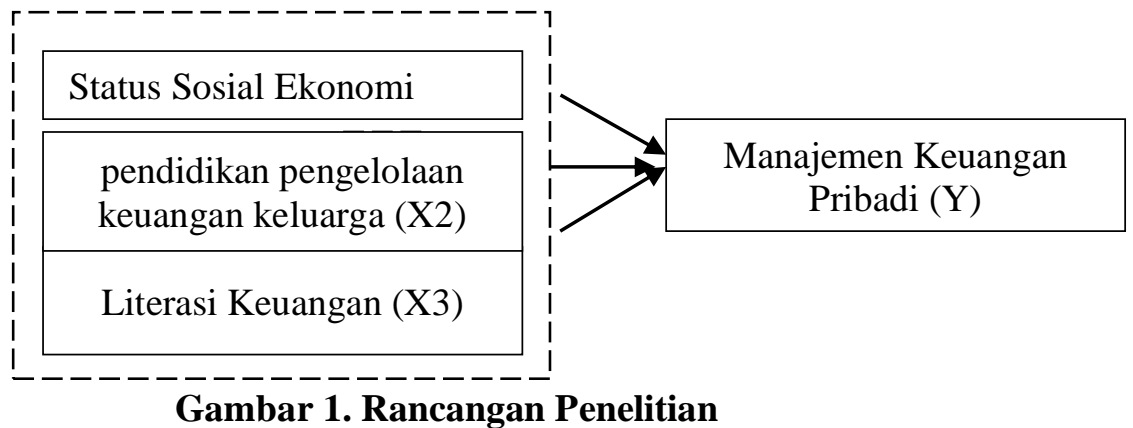

Gambar 1. Rancangan Penelitian

Keterangan :

$\longrightarrow \quad$ : Pengaruh Parsial 

terhadap Manajemen Keuangan Pribadi Siswa Akuntansi SMK - Mega Zullyana Dewi, Agung Listiadi DOI: https://doi.org/10.31004/edukatif.v3i6.965

Pengumpulan data dalam riset ini yaitu menggunakan angket atau kuisioner dengan menggunakan tes. Riset ini memanfaatkan angket dengan skala likert untuk memperoleh informasi tentang karakteristik status sosial ekonomi keluarga, pengaruh pendidikan pengaturan keuangan keluarga, dan sikap manajemen finansial pribadi. Tes digunakan untuk mengukur pengetahuan siswa dalam bidang manajemen keuangan yang disesuaikan dengan materi dalam mata pelajaran pengantar akuntansi dan akuntansi keuangan. Teknik analisis data dalam penelitian ini dengan menggunakan analisis non parametric Kendall's Tau-b yang digunakan untuk mengukur pengaruh secara parsial dalam variabel independen terhadap variabel dependen. Hipotesis pada penelitian ini yaitu:

$\mathrm{H}_{1} \quad$ : Diduga ada pengaruh status sosial ekonomi terhadap manajemen keuangan pribadi siswa akuntansi SMK Ipiems Surabaya

$\mathrm{H}_{2} \quad$ : Diduga ada pengaruh pendidikan pengelolaan keuangan keluarga terhadap manajemen keuangan pribadi siswa akuntansi SMK Ipiems Surabaya

$\mathrm{H}_{3}$ : Diduga ada pengaruh literasi keuangan terhadap manajemen keuangan pribadi siswa akuntansi SMK Ipiems Surabaya

\section{HASIL DAN PEMBAHASAN PENELITIAN}

Uji analisis Kendall's Tau-b merupakan salah satu uji statistika non parametrik. Uji Kendall's Tau-b merupakan metode pengukuran tentang keeratan hubungan atau dampak yang terdapat antara variabel X dan variabel Y dengan keadaan tidak diketahui disribusinya atau tidak berdistribusi normal (Djarwanto, 1999). Metode Kendall-Correlation Coefficient dikemukakan pada tahun 1983 oleh Murice G. Kendall. Koefisien korelasi uji Kendall dinotasikan menggunakan $\tau$ merupakan huruf yunani yang dibaca tau.

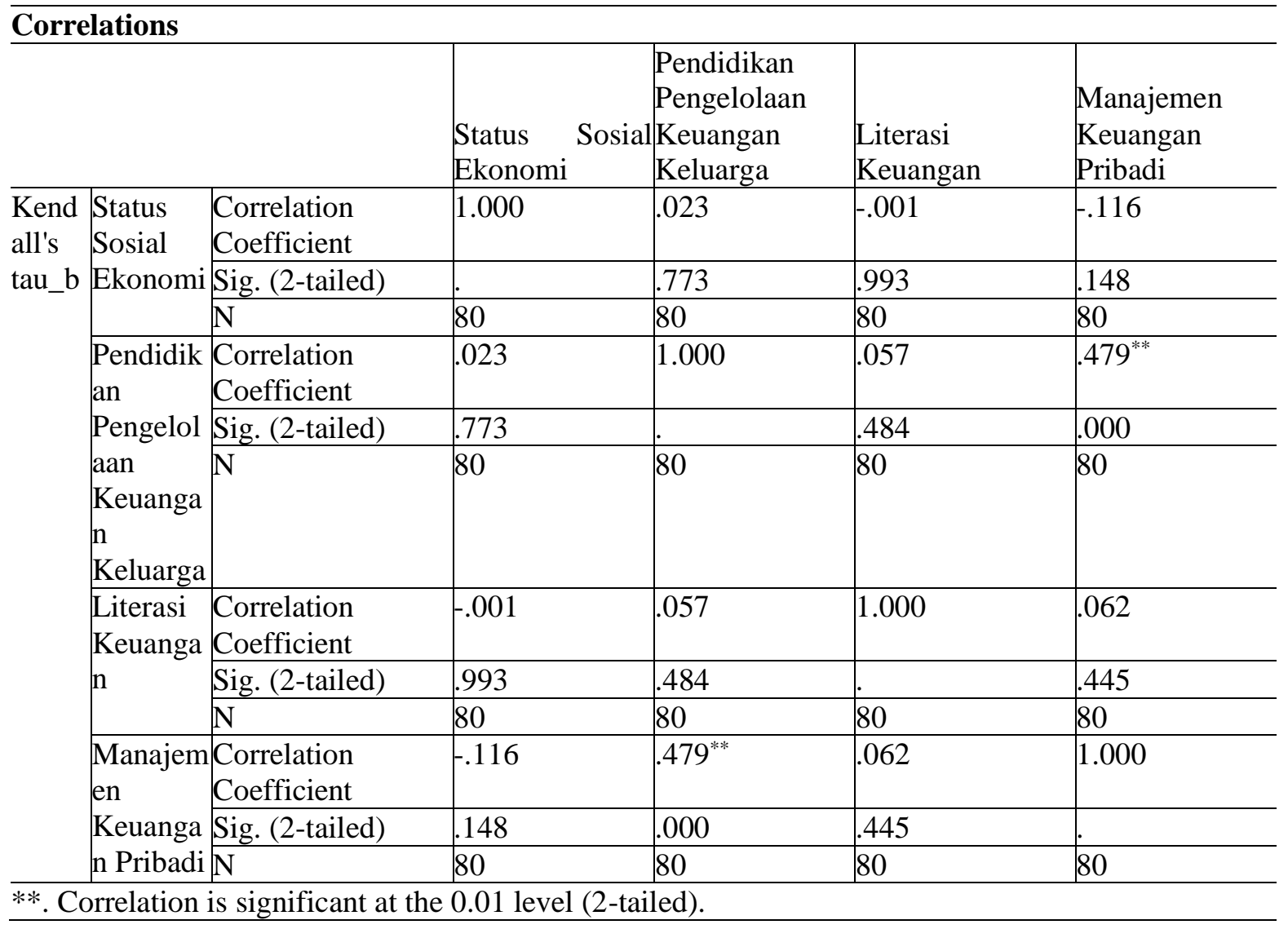


Berdasarkan dari output uji non parametric Kendall's Tau-b tersebut dapat diketahui nilai signifikansi atau nilai sig. (2-tailed) yang terdapat antara variabel independen status sosial ekonomi, pendidikan pengelolaan keuangan keluarga, dan literasi keuangan terhadap variabel dependen manajemen keuangan pribadi adalah sebesar 0,148; 0,000; dan 0,445. Jika besar nilai signifikansi $<0,05$ maka dapat diketahui terdapat dampak yang terjadi antara variabel tersebut. Namun, jika besar nilai signifikansi $>0,05$ maka dapat diketahui tidak terdapat pengaruh yang terjadi antara variabel tersebut. Sehingga dapat disimpulkan variabel status sosial ekonomi terhadap variabel manajemen keuangan pribadi mempunyai nilai signifikansi yaitu $0,148>0,05$ yang memiliki arti tidak signifikan atau tidak terdapat pengaruh antara variabel status sosial ekonomi terhadap variabel manajemen keuangan pribadi. Variabel independen pendidikan pengelolaan keuangan keluarga terhadap variabel manajemen keuangan pribadi memiliki nilai signifikansi yaitu 0,000< 0,05 yang memiliki arti signifikan atau adanya pengaruh antara variabel pendidikan pengelolaan keuangan keluarga terhadap variabel manajemen keuangan pribadi. Variabel literasi keuangan terhadap variabel manajemen keuangan pribadi memiliki nilai signifikansi yaitu 0,445>0,05 yang memiliki arti tidak signifikan atau tidak adanya pengaruh antara variabel literasi keuangan dengan variabel manajemen keuangan pribadi.

Sesuai dari output uji non parametric Kendall's Tau-b diatas dapat diketahui bahwa koefisien korelasi yang ada antara variabel independen status sosial ekonomi dan variabel dependen manajemen keuangan pribadi adalah sebesar -0,116. Sehingga dapat disimpulkan bahwa pengaruh antara variabel status sosial ekonomi dengan variabel manajemen keuangan pribadi adalah "sangat lemah". Koefisien korelasi antara variabel pendidikan pengelolaan keuangan keluarga dengan variabel manajemen keuangan pribadi adalah senilai $0,479^{* *}$. Sehingga dapat ditarik kesimpulan bahwa pengaruh antara variabel pendidikan pengelolaan keuangan keluarga dengan variabel manajemen keuangan pribadi adalah "cukup" dengan pengaruh yang terbentuk signifikan pada angka signifikansi sebesar 0,01 artinya standart penelitian lebih dipercaya dengan tingkat kesalahan sebesar $1 \%$. Koefisien korelasi yang terjadi antara variabel literasi keuangan dengan variabel manajemen keuangan pribadi yaitu senilai 0,062 . Sehingga dapat ditarik kesimpulan yaitu pengaruh variabel literasi keuangan terhadap variabel manajemen keuangan pribadi adalah "sangat lemah".

Berdasarkan dari output uji Kendall's Tau-b diatas dapat ditemukan bahwa koefisien korelasi yang ada antara variabel independen status sosial ekonomi dengan variabel dependen manajemen keuangan pribadi bernilai negatif yaitu sebesar $-0,116$. Sehingga dapat ditarik kesimpulan bahwa adanya pengaruh negatif atau tidak searah dalam variabel status sosial ekonomi dengan variabel manajemen keuangan pribadi. Pengaruh negatif bermakna jika semakin meningkat tingkat sosial ekonomi maka semakin buruk manajemen keuangan pribadi dan begitu juga sebaliknya. Koefisien korelasi antara variabel pendidikan pengelolaan keuangan keluarga dengan variabel manajemen keuangan pribadi bernilai positif yaitu senilai 0,479 . Sehingga dapat ditarik kesimpulan yaitu adanya pengaruh positif atau searah antara variabel pendidikan pengelolaan keuangan keluarga dengan variabel manajemen keuangan pribadi. Pengaruh positif bermakna jika semakin baiknya pendidikan pengelolaan keuangan keluarga akan membuat semakin baiknya manajemen keuangan pribadi. Koefisien korelasi dalam variabel independen literasi keuangan dengan variabel dependen manajemen keuangan pribadi yaitu sebesar 0,062. Sehingga dapat ditarik kesimpulan yaitu adanya pengaruh positif yang terjadi antara variabel literasi keuangan dengan variabel manajemen keuangan pribadi. Pengaruh positif bermakna jika semakin meningkatnya literasi keuangan seseorang akan membuat semakin baiknya manajemen keuangan pribadi.

Berdasarkan intepretasi uji Kendall's Tau-b diatas dapat ditarik kesimpulan bahwa pengaruh yang ada antara status sosial ekonomi terhadap manajemen keuangan pribadi siswa akuntansi SMK Ipiems Surabaya adalah tidak signifikan, sangat lemah, dan tidak searah. Hasil riset ini sesuai dalam penelitian (Chotimah, Chusnul; Rohayati, 2015) yaitu status sosial ekonomi kedua orang tua tidak memiliki pengaruh baik yang signifikan terhadap manajemen keuangan pribadi. Status sosial ekonomi yang dimiliki kedua orang tua siswa akuntansi SMK Ipiems Surabaya tidak berdampak terhadap manajemen keuangan pribadi siswa akuntansi 
SMK Ipiems Surabaya. Semakin meningkat sosial ekonomi kedua orang tua tidak membuat anak menjadi baik dalam manajemen keuangan pribadi anak tersebut, begitu juga jika semakin rendah tingkat sosial ekonomi kedua orang tua tidak membuat anak menjadi semakin buruk dalam manajemen keuangan pribadi anak tersebut. Pada kenyataannya diketahui bahwa kondisi yang terjadi pada siswa akuntansi SMK Ipiems Surabaya adalah kondisi sosial ekonomi kedua orang tua dengan kedudukan yang tinggi serta pendapatan lebih besar tidak membuat penambahan wawasan yang lebih luas untuk mendukung manajemen keuangan pribadi anak. Penelitian ini bertentangan dengan penelitian yang dilakukan oleh Ahmadi (dalam Chotimah, Chusnul; Rohayati, 2015) yang menyatakan tentang status sosial ekonomi orang tua yang memiliki dampak dalam pengalaman dan tindakan pada anak.

Pengaruh antara pendidikan pengelolaan keuangan terhadap manajemen keuangan pribadi siswa akuntansi SMK Ipiems Surabaya adalah signifikan, cukup, dan searah. Hasil riset ini sesuai dengan riset (Shim et al., 2010) yang mengemukakan bahwa pembelajaran moneter yang diadaptasi individu adalah melalui sikap keuangan yang dicontohkan orang tua. Riset ini menunjukkan pendidikan pengelolaan keuangan keluarga siswa SMK Ipiems Surabaya memiliki pengaruh terhadap manajemen keuangan pribadi siswa akuntansi SMK Ipiems Surabaya. Semakin baik pendidikan pengelolaan keuangan keluarga yang terbentuk akan membuat manajemen keuangan pribadinya semakin baik. Manajemen keuangan pribadi berkondisi baik terbentuk berdasarkan pendidikan pengelolaan keuangan yang berasal dari keluarga anak tersebut. Hal ini berarti pendidikan pengelolaan keuangan keluarga yang didapatkan oleh siswa akuntansi SMKI piems.

Surabaya memiliki pengaruh yang baik terhadap manajemen keuangan pribadi siswa. Hal ini berbeda dengan riset yang telah dikerjakan oleh (Chotimah, Chusnul; Rohayati, 2015) yaitu individu yang telah mendapatkan pendidikan keuangan dari orang tua sejak dini seharusnya dapat melakukan manajemen keuangannya dengan bijak, namun pada kenyataan masih buruk dalam manajemen keuangan.

Pengaruh antara literasi keuangan terhadap manajemen keuangan pribadi siswa akuntansi SMK Ipiems Surabaya adalah tidak signifikan, sangat lemah, dan searah. Hasil penelitian ini sesuai dengan penelitian (Maulita \& Mersa, 2017) bahwa ternyata variabel literasi keuangan belum mampu memberikan pengaruh terhadap manajemen keuangan pribadi mahasiswa politeknik negeri samarinda. Pendidikan pengelolaan keuangan dalam keluarga tidak mempunyai pengaruh terhadap manajemen keuangan pribadi siswa akuntansi SMK Ipiems Surabaya. Semakin meningkat literasi keuangan siswa tidak membuat manajemen keuangan pribadi siswa semakin baik, begitu juga jika semakin rendah tingkat literasi keuangan siswa tidak akan membuat manajemen keuangan pribadi siswa semakin buruk. Literasi keuangan yang tidak diterapkan dapat membuat anak tidak dapat melakukan manajemen keuangan pribadinya dengan baik. Hal ini bertentangan dengan penelitian (Laily, 2016) yang menyebutkan bahwa literasi keuangan mempunyai pengaruh secara langsung dalam perilaku keuangan.

\section{KESIMPULAN}

Berdasarkan hasil riset disimpulkan tidak adanya pengaruh status sosial ekonomi terhadap manajemen keuangan pribadi siswa akuntansi SMK Ipiems Surabaya, terdapat pengaruh pendidikan pengelolaan keuangan keluarga terhadap manajemen keuangan pribadi siswa akuntansi SMK Ipiems Surabaya, dan tidak adanya pengaruh literasi keuangan terhadap manajemen keuangan pribadi siswa akuntansi SMK Ipiems Surabaya.

\section{DAFTAR PUSTAKA}

Anggraini, V., \& Karneli, Y. (2021). Konseling Individual Menggunakan Teknik Parenting Untuk Membangun Karakter Siswa. Edukatif: Jurnal Ilmu Pendidikan, 3(3), 935-942. 
3551 Pengaruh Status Sosial Ekonomi, Pendidikan Pengelolaan Keuangan Keluarga dan Literasi Keuangan terhadap Manajemen Keuangan Pribadi Siswa Akuntansi SMK-Mega Zullyana Dewi, Agung Listiadi DOI: https://doi.org/10.31004/edukatif.v3i6.965

Https://Doi.Org/10.31004/Edukatif.V3i3.456

Astuti, R. P. F. (2016). Pengaruh Status Sosial Ekonomi Orang Tua, Literasi Ekonomi Dan Life Style Terhadap Perilaku Konsumsi Mahasiswa Jurusan Pendidikan Ekonomi Ikip Pgri Bojonegoro. Jurnal Edutama, 3(2), 49-58.

Chotimah, Chusnul; Rohayati, S. (2015). Pengaruh Pendidikan Keuangan Di Keluarga, Sosial Ekonomi Orang Tua, Pengetahuan Keuangan, Kecerdasan Spiritual, Dan Teman Sebaya Terhadap Manajemen Keuangan Pribadi Mahasiswa S1 Pendidikan Akuntansi Fakultas Ekonomi Universitas Negeri Surabaya. Jurnal Pendidikan Akuntansi (Jpak), 3(2), 3.

Chotimah, L. N., Ani, H. M., \& Widodo, J. (2017). Pengaruh Status Sosial Ekonomi Orang Tua Terhadap Prestasi Belajar Siswa (Studi Kasus Siswa Kelas Viii Smp Negeri 1 Jember Tahun Ajaran 2016/2017). Jurnal Pendidikan Ekonomi: Jurnal Ilmiah Ilmu Pendidikan, Ilmu Ekonomi Dan Ilmu Sosial, $11(1), 75$. Https://Doi.Org/10.19184/Jpe.V11i1.5004

Cude, B. J. (2006). College Students And Financial Literacy : What They Know And What We Need To Learn College Students And Financial Literacy : What They Know And What We Need To Learn. January.

Dew, J., \& Xiao, J. J. (2011). The Financial Management Behavior Scale : Development And Validation. 435, 43-59.

Djarwanto. (1999). Statistik Non Parametrik (Ketiga).

Laily, N. (2016). Pengaruh Literasi Keuangan Terhadap Perilaku Mahasiswa Dalam Mengelola Keuangan. Journal Of Accounting And Business Education, 1(4). Https://Doi.Org/10.26675/Jabe.V1i4.6042

Mandell, L. (2008). Financial Literacy Of High School Students. Handbook Of Consumer Finance Research, 163-183. Https://Doi.Org/10.1007/978-0-387-75734-6_10

Margaretha, F., \& Arief, P. R. (2015). Tingkat Literasi Keuangan Pada Mahasiswa S-1 Fakultas Ekonomi. Jurnal Manajemen Dan Kewirausahaan, 17(1), 76-85. Https://Doi.Org/10.9744/Jmk.17.1.76

Maulita, \& Mersa, N. A. (2017). Pengaruh Literasi Keuangan Terhadap Pengelolaan Keuangan Pribadi Pada Mahasiswa Di Politeknik Negeri Samarinda. Seminar Nasional Inovasi Teknologi Terapan, 136-143.

Nidar, S. R., \& Bestari, S. (2012). Personal Financial Literacy Among University Students (Case Study At Padjadjaran University Students , Bandung, Indonesia). World Journal Of Social Sciences, 2(4), 162171.

Rahayu, W. P. (2011). Analisis Intensitas Pendidikan Oleh Orang Tua Dalam Kegiatan Belajar Anak , Status Sosial Ekonomi Orang Tua Terhadap Motivasi Belajar Dan Prestasi Belajar Siswa. Jurnal Pendidikan Dan Pembelajaran, 18(April), 72-80.

Rosa, I., \& Listiadi, A. (2020). Pengaruh Literasi Keuangan, Pendidikan Keuangan Di Keluarga, Teman Sebaya, Dan Kontrol Diri Terhadap Manajemen Keuangan Pribadi. Jurnal Manajemen, 12(2), $244-252$.

Saifi, S., \& Mehmood, T. (2011). Effects Of Socioeconomic Status On Students Achievement. April, 119-128.

Shim, S., Barber, B. L., Card, N. A., Xiao, J. J., \& Serido, J. (2010). Financial Socialization Of First-Year College Students: The Roles Of Parents, Work, And Education. Journal Of Youth And Adolescence, 39(12), 1457-1470. Https://Doi.Org/10.1007/S10964-009-9432-X

Suhartini, D. Dan J. A. R. (2007). Pengelolaan Keuangan Keluarga Pedagang Etnis Cina Dwi Suhartini * Jefta Ardhian Renanta **. 7(2), 70-81.

Sundarasen, S. D. D., Rahman, M. S., \& Danaraj, J. (2016). Impact Of Financial Literacy , Financial Socialization Agents, And Parental Norms On Money Management. January.

Syuliswati, A. (2020). Pendidikan Pengelolaan Keuangan Keluarga, Gaya Hidup, Pembelajaran Serta Pengaruhnya Terhadap Literasi Keuangan. Akutansi Bisnis \& Manajemen ( Abm ), $27(1), 53$. Https://Doi.Org/10.35606/Jabm.V27i1.553 
3552 Pengaruh Status Sosial Ekonomi, Pendidikan Pengelolaan Keuangan Keluarga dan Literasi Keuangan terhadap Manajemen Keuangan Pribadi Siswa Akuntansi SMK - Mega Zullyana Dewi, Agung Listiadi DOI: https://doi.org/10.31004/edukatif.v3i6.965

Yushita, A. N. (2017). Pentingnya Literasi Keuangan Bagi Pengelolaan Keuangan Pribadi. Nominal, Barometer Riset Akuntansi Dan Manajemen, 6(1). Https://Doi.Org/10.21831/Nominal.V6i1.14330

Yuwan Lestari, S. (2020). Pengaruh Pendidikan Pengelolaan Keuangan Di Keluarga, Status Sosial Ekonomi, Locus Of Control Terhadap Literasi Keuangan (Pelajar Sma Subang). Prisma (Platform Riset Mahasiswa Akuntansi), 01(02), 69-78. 